\title{
The Problematic Revival of MURder Under SECTION 229(C) OF THE CRIMINAL CODE
}

\author{
KENT ROACH*
}

This article examines the increased use of the murder offence under s. 229(c) of the Criminal Code. It outlines how the objective foresight of death arm of s. 229(c) was struck down by the Supreme Court of Canada in R. v. Martineau, but still has not been repealed by Parliament. Three unfortunate cases are examined where trial judges erred by leaving the jury a copy of s. 229(c) with its unconstitutional objective arm present. The article examines the pre-Charter jurisprudence on s. 229(c) and suggests that the requirement that the accused have an unlawful object that is distinct from the actions that led to the death of the victim is still an important requirement. It then focuses on the second and most important mens rea requirement of s. 229(c), namely the requirement that the accused know that death was likely to occur. This fault requirement is examined and contrasted with recklessness and objective foresight of death, both of which are not constitutionally sufficient for a murder conviction. It is argued that some recent cases have treated accidental deaths during the pursuit of an unlawful object as murder under s. 229(c) and that such a result violates $s .7$ of the Charter, including principles of fundamental justice that accidental deaths not be punished as murder and that unintentional harms not be punished as severely as intentional harms.
Cet article examine le plus grand recours de l'accusation de meurtre en vertu de l'article 229(c) du Code criminel. Il énonce de quelle manière la Cour suprême du Canada a cassé, avec la prévoyance objective de mort, l'article 229(c) dans R. c. Martineau; cet article n'a cependant toujours pas été révoqué par le Parlement. Trois malheureuses causes sont examinées où les juges de première instance ont fait une erreur en donnant au jury une copie de l'article 229(c) avec ses dispositions non constitutionnelles. L'article examine la jurisprudence datant d'avant la Charte relative à l'article 229(c) et laisse entendre que l'exigence pour l'accusé d'avoir un objet illégal distinct des actions qui ont mené à la mort de la victime demeure une exigence importante. L'article passe ensuite à la deuxième exigence de l'article 229(c) et celle qui est la plus importante, à savoir l'intention coupable, c'est-à-dire l'exigence que l'accusé savait que la mort était probable. Cette exigence en matière de faute est étudiée et mise en opposition avec l'insouciance et la prévoyance objective de mort qui, sur le plan constitutionnel, sont insuffisantes pour une condamnation pour meurtre. On a fait valoir dans certaines causes récentes ont traité la mort accidentelle pendant la poursuite d'un objet illégal comme étant un meurtre en vertu de l'article 229(c) et que cela enfreint l'article 7 de la Chartre, incluant les principes fondamentaux de justice qu'une mort accidentelle ne peut pas faire l'objet de la même peine qu'un meurtre et le dommage involontaire ne peut pas faire l'objet de la même peine que le dommage intentionnel.

\section{TABLE OF ConTENTS}

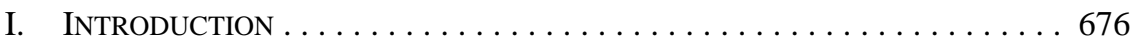

II. SECTION 229(C) IN ITS LEGISLATIVE CONTEXT

AND AS REVISED BY MARTINEAU $\ldots \ldots \ldots \ldots \ldots \ldots \ldots \ldots \ldots . \ldots 678$

III. THE PRE-CHARTER JURISPRUdENCE ON SECTION 229(C) $\ldots \ldots \ldots \ldots 679$

A. The Unlawful Object Requirement $\ldots \ldots \ldots \ldots \ldots \ldots . \ldots 60$

B. KNOWLEDGE OF THE LIKELIHOOD OF DEATH

AND ACCIDENTAL DEATHS $\ldots \ldots \ldots \ldots \ldots . \ldots . \ldots . \ldots . \ldots 61$

Professor of Law and Prichard Wilson Chair in Law and Public Policy, University of Toronto. I thank Tom McConnell and the staff of the Bora Laskin Law Library for excellent research assistance. I thank Sanjeev Anand, Michael Code, Patrick Healy, Zannah Johnston, Jill Presser, and Hamish Stewart for helpful comments on an earlier draft of this article. 
IV. The Constitutionally Required MENS REA FOR Murder:

KNOWLEDGE OF THE LIKELIHOOD OF DEATH . . . . . . . . . . . . . . . . . . 682

A. Is Reckless Murder Constitutional? . . . . . . . . . . 683

B. The Significance of Martineau for SECTION 229(C) . . . . . . 684

V. THREE EMBARASSING MistaKes: THE CONSEQUENCES

OF LEAVING SECTION 229(C) AS WRITTEN TO THE JURY . . . . . . . . . . 685

VI. THE REVIVIAL Of SECTION 229 (C) . . . . . . . . . . . . . . . . . 687

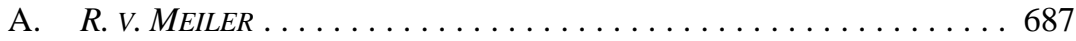

B. SubJeCtive Foresight OF DeAth In SECTION 229(C):

What Does it REALly REQUiRE? . . . . . . . . . . . . . 690

C. The Toronto Arson CASES . . . . . . . . . . . . . 690

D. AN UnNECESSARy USE Of SECTION 229(C) In MANitOBA . . . . . 693

E. R. V. J.S.R. A.K.A. THE JANE CREBA CASE . . . . . . . . . . . . . . . . 694

VII. What IS TO BE Done ABout Section 229(C)? . . . . . . . . . . . . . . 697

A. Clarifying WhAT "SUBJECTIVE Foresight

OF DEATH” ACTUALLY MEANS . . . . . . . . . . . . . . . . . . . . . . 697

B. Accidental Deaths Should Not Be Punished as

Murder: A NeW PRinciple of Fundamental JustiCE $\ldots . . \ldots 699$

C. Unintentional Harm ShOUld Not Be Punished as

SEVERELY AS INTENTIONAL HARM: AN EXISTING PRINCIPLE

OF FUNDAMENTAL JUSTICE . . . . . . . . . . . . . . 699

D. Clarifying the Importance of SEction 229(B) . . . . . . . . 700

E. ClaRIfYing THE MENS REA REQUIREMENTS

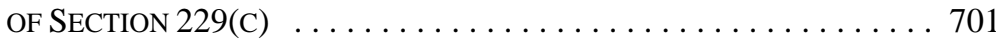

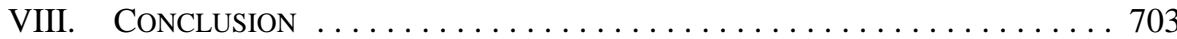

\section{INTRODUCTION}

In the aftermath of the fundamental reforms to the law of murder in Martineau, ${ }^{1}$ s. 229(c) of the Criminal Code appeared to be a dead letter. ${ }^{2}$ The Court in Martineau made clear that the reference in s. 229(c) to murder liability on the basis that the accused "ought to know" that the pursuit of an unlawful object would cause death violated the constitutionally required mens rea of knowledge of the likelihood of death for murder. Moreover, it could not be justified as a reasonable limit on the accused's rights under ss. 7 and 11(d) of the Canadian Charter of Rights and Freedoms. ${ }^{3}$ In the wake of this ruling, s. 229(c) was frequently forgotten in the classroom, annotated criminal codes, and handbooks of jury instructions.

Recent jurisprudence, including the use of s. 229(c) in prosecutions arising from the killing of Jane Creba in a boxing day shootout on Toronto's Yonge Street and for accidental

R. v. Martineau, [1990] 2 S.C.R. 633 [Martineau]. In that case, the Court declared the constructive murder provision in the Criminal Code, R.S.C. 1985, c. C-46, s. 230(1), to be of no force and effect because it did not require the constitutionally required mens rea of subjective knowledge of death. Three years earlier, the Court struck down s. 230(4) of the Criminal Code on the basis that it did not even ensure that there was objective foresight of death before a person was convicted for a killing with a firearm during the commission of a serious crime such as robbery: R. v. Vaillancourt, [1987] 2 S.C.R. 636 [Vaillancourt].

Criminal Code, ibid., s. 229(c).

Part I of the Constitution Act, 1982, being Schedule B to the Canada Act 1982 (U.K.), 1982, c. 11 [Charter]. 
deaths arising from a Toronto arson, however, suggests that s. 229(c) is making a comeback. The revival of s. 229(c) raises many troubling questions. The most important of these issues are whether the increased use of s. 229(c) is resulting in a de facto form of reckless, negligent, or even constructive murder and whether the section, even without its objective arm, can be applied in a constitutional manner.

The Supreme Court will eventually have to address a Charter issue that it did not squarely confront in Martineau; namely whether it is constitutional to impose the stigma and penalty of a murder conviction on a person who did not intend to kill or even harm any particular person, but who pursued an unlawful objective with subjective knowledge that some person might die as a result. Although the Court has rejected the idea defended in dissent by L'Heureux-Dubé and Sopinka JJ. that objective foresight of death should be a constitutionally sufficient form of fault for murder, ${ }^{4}$ it has not yet clearly addressed whether recklessness in the form of subjective advertence to the risk or possibility of death as opposed to knowledge of the probability of death is a constitutionally sufficient form of fault for murder. The question for Canadian courts will not be whether reckless or negligent murder constitutes good policy, ${ }^{5}$ but whether departures can be justified from the constitutional requirement that a person should only be branded and punished as a murderer if he or she has subjective knowledge of the likelihood of death. In addressing these questions, the Court will also have to consider the wide gulf between a law of murder that requires subjective knowledge of death and a law of manslaughter that covers an array of killings ranging from subjectively reckless killings to killings where an unlawful act is committed with objective foreseeability of non-trivial bodily harm. ${ }^{6}$

The most sympathetic cases under s. 229(c) should not arise from the killing of Ms. Creba or other cases where the accused intended to kill or seriously harm another person, but killed someone else. The transferred intent provisions of s. 229(b) already recognize the intuitive sense that an intentional murderer should not benefit from such mistakes. At the same time, courts seem curiously reluctant to apply s. 229(b) in such situations even while they breathe life into the far more problematic s. 229(c).

The most problematic cases under s. 229(c) are those where someone dies in an unexpected and indeed accidental manner while the accused pursues an inherently dangerous unlawful object. As will be seen, there is a temptation in the new case law to conclude that the inherently dangerous nature of the unlawful object means that the accused must have

$4 \quad$ Negligent murder was recognized by the House of Lords in the oft-criticized case of Director of Public Prosecutions v. Smith (1960), [1961] 1 A.C. 290 (H.L.) [Smith], but this decision was not followed in either Canada or Australia and it was subsequently changed by legislative amendment in the United Kingdom: see Criminal Justice Act 1967 (U.K.), 1967, c. 80, s. 8. In New Zealand, the outcry against Smith led to legislative repeal of the objective arm with respect to unlawful object murder: see Crimes Act 1961 (N.Z.), 1961/43, s. 167(d).

The Law Reform Commission of Canada rejected an offence of reckless murder on the basis that "[a] reckless killer is one who gambles with his victim's life” and concluded that, while culpable, this form of fault should not be associated with intentional killings: Law Reform Commission of Canada Homicide (Working Paper 33) (Ottawa: Minister of Supply and Services Canada, 1984) at 53. The Law Commission of England and Wales has, however, more recently advocated a form of reckless murder in the form of awareness of a risk that the victim would die: U.K., The Law Commission, Murder, Manslaughter and Infanticide (Project 6 of the Ninth Programme of Law Reform: Homicide, Law Com No 304) (London: The Stationery Office, 2006), online: The Law Commission <http://www.lawcom. gov.uk/docs/lc304.pdf>. 
known that someone would die. Such reasoning, however, strains foundational distinctions between subjective and objective fault. It also discounts the requirement under s. 229(c) and under Martineau that a murderer must have guilty knowledge of a likelihood of death and that this knowledge should exist at the time that death is caused to the victim. It opens up the disturbing possibility that people will be convicted of murder for accidental deaths that occur during the pursuit of an unlawful object. In other words, it opens up the possibility of murder convictions for constructive homicides that should otherwise be treated as manslaughters.

There are a number of other important but subsidiary issues that arise from the revival of s. 229(c). One is that the extensive and complex pre-Charter jurisprudence on that provision has to be dusted off and re-evaluated in light of new constitutional norms. Much of this jurisprudence revolved around the thorny requirement in s. 229(c) for an unlawful object that is distinct from the actions that killed the victim. ${ }^{7}$ Before the Charter, this requirement was used as a means to restrain the use of negligent murder under s. 229(c), something that has always been deeply problematic. Now that the objective arm of s. 229(c) has been struck down, there is a danger that courts will downplay the requirement for a distinct unlawful purpose. ${ }^{8}$ Nevertheless, the requirement of a distinct unlawful purpose should be maintained. It is clearly required by the language of s. 229(c) and it is necessary to ensure that s. 229(c) does not eclipse the other forms of murder in s. 229.

Much of the pre-Charter s. 229(c) jurisprudence focused on the unlawful object requirement. There is a danger that this mens rea requirement will be emphasized over the second mens rea requirement that the accused know that his or her actions are likely to cause death. It will be suggested that some recent cases have glossed over this second mens rea requirement even though it is clearly required by the text of s. 229(c), and it is required under Martineau to ensure that s. 229(c) satisfies the constitutional mens rea requirement of subjective knowledge of the likelihood of death. More precision is required in articulating this second critical mens rea requirement. The revived jurisprudence under s. 229(c) also raises the issue of whether convicting someone for an accidental death that occurs in the pursuit of an unlawful object in itself violates the principles of fundamental justice protected in s. 7 of the Charter, including the principle that unintentional harms not be punished as severely at intentional harms.

\section{SECTION 229(C) IN ITS LEGISLATIVE CONTEXT AND AS REVISED BY MARTINEAU}

Any discussion of s. 229(c) should take place in the larger context of the murder provisions of s. 229 of the Criminal Code. Section 229 provides:

Culpable homicide is murder

(a) where the person who causes the death of a human being

\footnotetext{
$7 \quad$ R. v. Vasil, [1981] 1 S.C.R. 469 [Vasil]; R. v. DeWolfe (1977), 13 O.R. (2d) 302 (C.A.) [DeWolfe]; $R$ v. Tennant (1975), 23 C.C.C. (2d) 80 (Ont. C.A.) [Tennant].

8 R. v. J.S.R., 2008 ONCA 544, 237 C.C.C. (3d) 305 [J.S.R.].
} 
(i) means to cause his death, or

(ii) means to cause him bodily harm that he knows is likely to cause his death, and is reckless whether death ensues or not;

(b)

where a person, meaning to cause death to a human being or meaning to cause him bodily harm that he knows is likely to cause his death, and being reckless whether death ensues or not, by accident or mistake causes death to another human being, notwithstanding that he does not mean to cause death or bodily harm to that human being; or

(c) where a person, for an unlawful object, does anything that he knows or ought to know is likely to cause death, and thereby causes death to a human being, notwithstanding that he desires to effect his object without causing death or bodily harm to any human being. ${ }^{9}$

When read in the context of the entire provision, s. 229(c) must be distinguished from cases under s. 229(a) where the accused means to cause death or bodily harm to a specific victim knowing that it is likely to cause death. Whereas s. 229(a) refers to a specific victim by the reference to "his death" and causing "him" bodily harm, s. 229(c) only refers to causing death to "a human being." The wider range of potential victims contemplated in s. 229(c) is underlined by the reference that the accused may be guilty under that section even though "he desires to effect his object without causing death or bodily harm to any human being."10

Leaving aside constitutional considerations, s. 229(c) must be interpreted in a manner that recognizes its independent force, but that does not eclipse the other murder offences. For example, if the unlawful object requirement is interpreted too broadly there is a danger that s. 229(c) will apply in cases where the accused has assaulted a particular victim meaning to cause that victim death or bodily harm. These scenarios should be covered by s. 229(a). On the other hand, s. 229(c) should not be interpreted so narrowly that it only applies in transferred intent cases that should be caught under s. 229(b) because the accused kills the victim by accident or mistake while intending to kill another person. On its face and without reference to Charter considerations, s. 229(c) expands murder beyond the intentional killing or infliction of bodily harm cases targeted by s. 229(a) and the transferred intent cases captured under s. 229(b) to include killings during the pursuit of unlawful objects of a broader range of victims. ${ }^{11}$ The question, however, is how far does s. 229(c) expand murder, and what precisely is required to sustain a murder conviction under that section?

\section{The Pre-Charter JuRisprudence ON SECTION 229(C)}

A significant and complex jurisprudence developed under s. 229(c) before the Charter, but that jurisprudence, like s. 229(c), has faded from view in recent years. The pre-Charter jurisprudence must now be revisited, albeit in light of the new constitutional standards for murder. 


\section{A. The UnLAWful OBJECT REQUIREMENT}

The leading case on the unlawful object requirement in s. 229(c) was Vasil, ${ }^{12}$ where the Supreme Court held that the unlawful object must be "clearly distinct from the immediate object of the dangerous (unlawful) act." This requirement addresses the danger that if s. 229(c) is interpreted too broadly it could eclipse the other murder provisions and in particular s. 229(a). In addition, the Court held that the unlawful object must be "conduct which, if prosecuted fully, would amount to a serious crime, that is an indictable offence requiring mens rea." ${ }^{13}$ This responded to basic legality concerns.

The unlawful object requirement was also fleshed out in two important decisions by the Ontario Court of Appeal that unfortunately do not sit easily together. In Tennant, ${ }^{14}$ the Ontario Court of Appeal held that the requirement for a further unlawful object could be satisfied in a case where the unlawful object was part of the overall course of conduct that led to an assault on the victim and the victim's death. The Court of Appeal expressed the concern that it would be a "startling result" not intended by Parliament if "one who does an act causing death in order to achieve an unlawful purpose necessarily involving the causing of bodily harm to another, is outside the subsection, whereas one whose objective does not necessarily entail the causing of bodily harm, and hence less culpable, may fall within it."15 A year later, however, the Ontario Court of Appeal in DeWolfe warned that Tennant should be seen as a "high-water" mark in s. 229(c) and not a "point of departure" lest there be an "overflowing [of] its banks" that would make murder "of almost every unlawful homicide."16 In the result, the Court of Appeal held that pointing a firearm was not a sufficiently distinct unlawful object to the shooting of the victim to constitute an unlawful object.

As will be seen, courts have been tempted to be even more flexible about the requirement of a distinct unlawful object once it is accepted that s. 229(c) will now require the Crown to prove, at a minimum, that the accused knew that death was likely to result from his or her actions. ${ }^{17}$ Nevertheless, the requirement of a further unlawful object should be retained if

\footnotetext{
Supra note 7 at 500 .

Ibid.

Supra note 7.

Ibid. at 94.

DeWolfe, supra note 7 at 308.

J.S.R., supra note 8; Don Stuart, Canadian Criminal Law: A Treatise, 5th ed. (Scarborough: Thomson Carswell, 2007) at 210: Professor Stuart has observed that "[a]ny resort to s. 229(c) will also unfortunately return the law of murder to former common law complexities of trying to identify an unlawful objective distinct from the immediate object accompanying the act of killing." Similarly the editors of a leading book of jury instructions caution that

DeWolfe establishes the test of determining whether the accused did "a single act or a single series of acts with but one single purpose” as opposed to, presumably, several discrete acts, committed, ultimately, for the purpose of obtaining an unlawful object. Whether the test can be applied without engaging in a "metaphysical examination to uncover further unlawful objects," which DeWolfe specifically warns against, is arguable.

(Gerry A. Ferguson, Michael R. Dambrot \& Elizabeth A. Bennett, Canadian Criminal Jury Instructions, 4th ed., looseleaf (Vancouver: The Continuing Legal Education Society of British Columbia, 2006) vol. 2 at 6.48-18.)

I agree that the requirement of further unlawful objects in DeWolfe and Vasil adds complexity to the law and is unfortunate to an alternative of abolition of s. 229(c). Nevertheless, if s. 229(c) is retained, the argument presented here will be that the requirement must be retained. For examples of the complexity in determining whether there is an unlawful object that is distinct from the acts that lead to the victim's death, see the divided Court of Appeal decisions in R. v. O'Connor (1989), 76 Sask. R. 130 (C.A.) [O’Connor] and R. v. Ryan (1989), 76 Nfld. \& P.E.I.R. 26 (Nfld. C.A.) [Ryan]. In the bizarre case of $O$ 'Connor, a majority held that there was no further unlawful object when a friend of the victim shot
} 
only to ensure that s. 229(c) does not eclipse ss. 229(a) and (b), which both require proof that the accused either meant to cause death or bodily harm to a particular person knowing that the harm is likely to cause death. Apart from constitutional considerations, courts have an obligation to interpret s. 229(c) in light of the other murder provisions in that section, and the requirement of proof of a distinct unlawful object is a critical difference between murder under s. 229(c) and murder under ss. 229(a) and (b).

\title{
B. KNOWLEDGE OF THE LIKELIHOOD OF DEATH AND ACCIDENTAL DEATHS
}

The pre-Charter jurisprudence unfortunately does not directly address what is required by the knowledge of the likelihood of death requirement in s. 229(c) and its relation to the statement that the provision can apply even though the accused desired to effect his unlawful object "without causing death or bodily harm to any human being." 18 This omission is understandable given that before Martineau, the prosecutor did not have to establish that the accused knew that death was likely to occur, but could rely on the objective arm of the section and an argument that the accused ought to have known that his or her actions were likely to cause death. Care must be taken in relying on the pre-Charter jurisprudence, because much of it relies on the objective arm of s. 229(c), which was struck down in Martineau. ${ }^{19}$

Before Vasil, the leading Supreme Court of Canada case on s. 229(c) was Hughes. ${ }^{20}$ That case involved whether a predecessor to s. 229(c) applied when a person was killed during a struggle in an armed robbery. Chief Justice Duff indicated that it was not necessary

\begin{abstract}
that the jury should have found that the acts of the defendants were such as they knew or should have known were likely to cause the very acts to be done or the precise situation to arise which in fact resulted in the homicide, or to cause the death of the person who was killed, but that it would suffice if the jury had found that the accused did an act which they knew or should have known would be likely to induce the doing of anything or to bring about any situation likely to cause the death of some person — the person killed or any other person. $^{21}$
\end{abstract}

The Court added that it was possible that the accused would be guilty because he ought to have known that a fatal struggle would result from his pursuit of the unlawful object of an armed robbery. Any use of Hughes today will have to account for its reliance on the unconstitutional objective arm of s. 229(c).

It would, however, be wrong to dismiss the relevance of Hughes as a precedent today. In that case, the Court placed some important limits on s. 229(c) to ensure that it would not apply to accidental deaths. In a neglected passage, it held that "[i]f the pistol went off accidentally ... it could hardly be said as matter of law to be an act of violence done by the

the victim in prison in an apparent and ill-conceived plan to help the victim escape from prison. In Ryan, a majority held that the accused's act of confronting her abusive spouse with a knife when attempting to retrieve her car keys was not an unlawful object distinct from her acts of stabbing her spouse.

Criminal Code, supra note 1, s. 229(c).

Supra note 1.

R. v. Hughes, [1942] S.C.R. 517 [Hughes].

Ibid. at 522, citing R. v. Graves (1913), 47 S.C.R. 568 at 583 [Graves]. 
accused 'in furtherance of or in the course of' the crime of robbery."22 In the case of such accidental deaths in the pursuit of an unlawful object, the appropriate disposition would be manslaughter. Hughes speaks to a long-standing recognition of the injustice of punishing someone for murder for an accidental death. It will be suggested below that this proposition should be recognized as a principle of fundamental justice under s. 7 of the Charter and that neglect of the principle also violates the principle of fundamental justice that unintentional harms not be punished as severely as intentional harms.

\title{
IV. The CONSTItUTIONALly REQUIRED MENS REA FOR MURDER: KNOWLEDGE OF THE LIKELIHOOD OF DEATH
}

In Martineau, the Supreme Court held that the stigma and penalty of a murder conviction required, as a minimum under s. 7 of the Charter, proof of subjective knowledge of the likelihood of death. Chief Justice Lamer explained:

\begin{abstract}
The rationale underlying the principle that subjective foresight of death is required before a person is labelled and punished as a murderer is linked to the more general principle that criminal liability for a particular result is not justified except where the actor possesses a culpable mental state in respect of that result.... In my view, in a free and democratic society that values the autonomy and free will of the individual, the stigma and punishment attaching to the most serious of crimes, murder, should be reserved for those who choose to intentionally cause death or who choose to inflict bodily harm that they know is likely to cause death. The essential role of requiring subjective foresight of death in the context of murder is to maintain a proportionality between the stigma and punishment attached to a murder conviction and the moral blameworthiness of the offender. ${ }^{23}$
\end{abstract}

It is clear from the italicized passage above that the constitutionally required mens rea for murder is knowledge of the likelihood of death as opposed to recklessness, which is a lower form of subjective mens rea only requiring advertence to the risk or possibility of death. ${ }^{24}$ The Court, however, did not define with precision what knowledge of the likelihood of death actually means. As will be seen, the failure of the Court to address this question is significant in determining the meaning of s. 229(c), which also now requires knowledge of the likelihood of death.

Hughes, ibid. at 523. The Court was also concerned about distinguishing murder from manslaughter in the earlier case of Graves when it quashed a murder conviction and ordered a new trial because the trial judge had left the jury with the impression that it "may have convicted of murder without at all considering whether the conduct of the accused was such that it was probable that it would cause the deceased to act in a manner likely to result in some person being killed": Graves, ibid. at 589.

23 Martineau, supra note 1 at 645-46 [emphasis added].

24 The difference between knowledge and recklessness in the context of murder was explained in $R$. $v$. Cooper, [1993] 1 S.C.R. 146 at 154-55 [Cooper], in which the Court stated that the reference to recklessness in s. 229(a)(ii) of the Criminal Code

can be considered an afterthought since to secure a conviction under this section it must be established that the accused had the intent to cause such grievous bodily harm that he knew it was likely to cause death. One who causes bodily harm that he knows is likely to cause death must, in those circumstances, have a deliberate disregard for the fatal consequences which are known to be likely to occur. That is to say he must, of necessity, be reckless whether death ensues or not. See also Nygaard, supra note 11 at 1088 . For further arguments that the reference to recklessness in s. 229(a)(ii) is redundant and potentially confusing, see Gary T. Trotter, "Instructing Juries on Murder and Intent” (2005) 24 C.R. (6th) 178. 


\section{A. Is Reckless MURder CONSTITUTIONAL?}

Courts in both Australia and New Zealand have refused, when interpreting their versions of s. 229(c), to require that the accused have knowledge of the probability of death as opposed to subjective awareness of or advertence to a significant risk of death. ${ }^{25}$ The result is the recognition of an offence of reckless murder in both countries. The distinct question in the Canadian context, however, is whether the recognition of reckless murder would be consistent with a constitutionally required mens rea for murder that was defined in Martineau with explicit reference to knowledge of the likelihood of death. ${ }^{26}$ The Ontario Court of Appeal in a series of cases has held that it is an error to instruct the jury with respect to the "chance" or "danger" of death under s. 229(a)(ii) as opposed to the likelihood of death. ${ }^{27}$ The same approach should apply under s. 229(c) both because of its explicit reference to knowledge of the likelihood of death and the similar constitutional mens rea requirement in Martineau.

In my view, Canadian courts should not recognize reckless murder as a constitutional form of murder. Although recklessness is an important and common form of subjective fault, it does not ensure that the accused is morally blameworthy enough to bear the special stigma and penalty of a murder conviction. A murderer is a person who deliberately and knowingly takes another's life. Although knowledge does not require that the accused know for certain that a person will die, it does require knowledge of the probability of death. A person who is reckless only adverts to the risk or possibility of death. Although this advertence is a form of subjective culpability, it falls short of the idea that a person has contemptuously and deliberately taken or disregarded another's life.

The constitutionally required mens rea for murder should take into account the critical difference between a murder conviction, which results in mandatory and automatic life imprisonment, and a manslaughter conviction, which in the absence of a mandatory minimum sentence, such as that which applies to killings with a firearm, results in the exercise of sentencing discretion. As Gibbs C.J. of the Australian High Court reasoned, admittedly in dissent, references to the likelihood of death refer to probabilities as opposed

Bougheyv. R., [1986] HCA 29, 161 C.L.R. 10, Mason, Wilson, and Deane JJ. [Boughey]. Note that two judges in dissent would have interpreted the provision to require that death be more probable than not. In New Zealand, the reference to likely death has been interpreted to include a real or substantial risk of death even in cases where death is not probable: R. v. Piri, [1987] 1 N.Z.L.R. 66 (C.A.) [Piri]. See also Timoti v. R., [2005] NZSC 37, [2006] 1 N.Z.L.R. 323 at para. 14 [Timoti], recognizing that an unlawful object murder "[u]sually... will involve less moral blameworthiness" than intentional murder. The Supreme Court has recently reformulated the mens rea of war crimes and crimes against humanity to include not only knowledge or wilful blindness of the circumstances but also the recklessness implicit in taking "the risk that they are part of the attack": Mugesera v. Canada, 2005 SCC 40, [2005] 2 S.C.R. 100 at para 176. Note that the Court in this case did not purport to overrule R. v. Finta, [1994] 1 S.C.R. 701, which restricted the mens rea to either knowledge or wilful blindness of the relevant circumstances. As I have argued elsewhere:

Although recklessness is a subjective form of fault that requires proof that the accused adverted to the prohibited risk, it is a lower and lesser form of fault than knowledge or even wilful blindness, which was previously the lowest constitutionally required fault element for war crimes.

Knowledge remains the minimal fault requirement under section 7 of the Charter with respect to murder and attempted murder.

(Kent Roach, Criminal Law, 4th ed. (Toronto: Irwin Law, 2009) at 68.)

$27 \quad$ R. v. Czibulka (2004), 189 C.C.C. (3d) 199 at paras. 62-70 (Ont. C.A.) [Czibulka]; R. v. Patterson (2006), 79 O.R. (3d) 257 at paras. 34-48 (C.A.) [Patterson]. See also R. v. Dempsey, 2002 BCCA 320, 165 C.C.C. (3d) 440 at paras. 27-30, also rejecting reckless murder. See generally Trotter, supra note 24. 
to possibilities. "If 'likely' ... were regarded as meaning 'possible', that provision would have a very drastic operation, since it would treat as murder a culpable homicide caused by any unlawful act which the offender knew would possibly cause death. A death in those circumstances might understandably be regarded as manslaughter, but it would be draconian to call it murder."28

Although the majority approaches in both Australia and New Zealand refuse to interpret references to likely death as requiring probable death, and as such open up the possibility of reckless forms of murder, they also recognize that some chances or risks of death will be too remote to merit the stigma and penalty of a murder conviction. ${ }^{29}$ In my view, it will be clearer for the jury to be directed in terms of probabilities than with respect to some undefined references to risks that are too remote or are not significant enough to merit a murder conviction. ${ }^{30}$ The majority approaches in Australia and New Zealand criticize the probability approach as imposing unrealistic demands for mathematical certainty, but a probability requirement is much clearer and easier to understand than the recognition of some undefined or difficult to define margin of risk that is too remote to merit a murder conviction.

\title{
B. THE SigNIFICANCE OF MARTINEAU FOR SECTION 229(C)
}

Although Martineau involved s. 230(a) of the Criminal Code, Lamer C.J.C., with the concurrence of four other judges, addressed the constitutionality of s. 229(c) by briefly concluding that because

\begin{abstract}
subjective foresight of death must be proven beyond a reasonable doubt before a conviction for murder can be sustained, and as a result, it is obvious the part of s. 212(c) [now s. 229(c)] of the Code allowing for a conviction upon proof that the accused ought to have known that death was likely to result violates ss. 7 and $11(d)$ of the Charter.... Although it would be open to save that part of s. 212(c) under s. 1 of the Charter, it seems to me that the attempt would fail for the reasons I have given in respect of the attempt to similarly save s. 213 of the Code. ${ }^{31}$
\end{abstract}

The Court concluded in Martineau that the objective arm of s. 230(a) of the Criminal Code in deterring the infliction of bodily harm during the commission of offences could be more proportionately achieved through conviction of offences other than murder.

If the past is any indication, s. 1 of the Charter is not likely to play an important role in any subsequent constitutional challenge to s. 229(c) of the Criminal Code. One factor is the Court's long-standing reluctance to accept any s. 1 justification for a violation of a s. 7 right. $^{32}$ The other

$28 \quad$ Boughey, supra note 25 at para. 4.

29 Piri, supra note 25 at 84 . For example, McMullin J. in the leading New Zealand case interprets the reference to likely death as being "a real or substantial risk. It need not be more probable than not but it should be more than a bare possibility.” For support for the Piri position see Isabel Grant, Dorothy Chunn \& Christine Boyle, The Law of Homicide, looseleaf (Scarborough: Carswell, 1994) at 4-45-46.

30 The Ontario Court of Appeal has cautioned about the dangers of trying to define the likelihood of death, but it also held that the trial judge's attempts to do so were not a reversible error in large part because of the emphasis that had been placed on the requirement of likely probabilities as opposed to recklessness and risks: $R$. v. Edelenbos (2004), 71 O.R. (3d) 698 at paras. 20-24 (C.A.).

Martineau, supra note 1 at 648-49.

32 Re B.C. Motor Vehicle Act, [1985] 2 S.C.R. 486; R. v. Ruzic, 2001 SCC 24, [2001] 1 S.C.R. 687. For my criticisms of this approach for ignoring the role of s. 1, the dialogic character of the Charter, and for diminishing the scope of the s. 7 right, see Kent Roach, "Common Law Bills of Rights as Dialogue Between Courts and Legislatures” (2005) 55 U.T.L.J. 733. 
factor is the Court's willingness to conclude in Martineau that Parliament's legitimate crime control objectives could be achieved more proportionately and without punishing people for murder who do not have fault that is commensurate to the stigma and penalty for our most serious offence.

For about a decade after the Court's felony murder decisions, prosecutors appeared to be unwilling to risk a successful Charter challenge by charging s. 229(c). ${ }^{33}$ At the same time, Parliament refused to amend s. 229(c) to remove the "ought to know" arm that a majority of the Supreme Court of Canada in Martineau strongly suggested was an unjustified violation of ss. 7 and 11(d) of the Charter because it substituted objective foresight of death for the constitutionally required mens rea of subjective foresight of death. As will be seen, Parliament's neglect of s. 229(c) contributed to some unnecessary mischief.

\section{THREE EMBARRASSING MistaKes: THE CONSEQUENCES OF LEAVING SECTION 229 (C) AS WRITTEN TO THE JURY}

In reported decisions from three provinces, murder convictions have been overturned and new trials ordered because the trial judge allowed the jury to read the text of s. 229(c). These are embarrassing mistakes that do little credit for the administration of justice. Leaving aside the question of whether juries should be allowed to have and possibly interpret copies of the complex text of the Criminal Code, the problem in these three cases is that Parliament has still not amended s. 229(c) to remove the objective arm found to be unconstitutional in Martineau almost 20 years ago. Parliament deserves criticism for not cleaning up the Criminal Code, but the trial judges and lawyers in these cases also deserve criticism for failing to edit s. 229(c) as it has been amended by Martineau.

In the mid-1990s, s. 229(c) was left to the jury in the trial of two youths who were alleged to have assaulted the victim and left him to drown in shallow water. The trial judge twice read the jury the provisions of s. 229(c) "as it appears in the Criminal Code." 34 He also paraphrased the provision for the jury twice, once including and once omitting the "ought to have known" phrase. $^{35}$ The trial judge corrected the reference to ought to have known at an earlier point in the trial, but not in the closing address to the jury two weeks later. ${ }^{36}$ Although it found the Crown's argument that there was no miscarriage of justice in this case "attractive because there was ample evidence in this case upon which a properly instructed jury could have found either or both accused guilty of murder," 37 the British Columbia Court of Appeal reluctantly held that the murder convictions must be quashed because it was impossible to know whether the jury relied on the objective arm. Thus, a complex case involving accomplice liability and pathology evidence had to be retried because of a combination of Parliament's and the trial judge's failures to act on the true state of the law with respect to s. 229(c).

Grant, Chunn \& Boyle, supra note 29 at 4-52.

R. v. D.A.H. (1997), 120 C.C.C. (3d) 533 at para. 43 (B.C.C.A.).

Ibid. at para. 44.

Ibid. at para. 42. Similar but less frequent errors were made in reference to the objective arm of s. 21(2), which is also inconsistent with the constitutionally required mens rea for murder.

Ibid. at para 48. 
In Salt, ${ }^{38}$ the Ontario Court of Appeal found that the trial judge, in a case where the Crown theory was based on a killing during a kidnapping and forcible confinement, had erred by leaving the jury with an unedited copy of s. 229(c). Like the British Columbia Court of Appeal before it, the Ontario Court of Appeal held that the leaving of the unedited version of s. 229(c) was fatal with the Court stressing the danger that the jury over two days of deliberation would focus on the unedited wording of s. 229(c). ${ }^{39}$ A new trial was only avoided in Salt because the Crown and the accused agreed to a manslaughter conviction that would see the accused (who had already served over six years imprisonment) being sentenced to eight years imprisonment for manslaughter.

The third case, Winmill, ${ }^{40}$ came from New Brunswick and involved another situation where the judge left the jury with a copy of s. 229(c) as it appears in the Criminal Code. The case was factually complex and involved two separate charges of first degree murder arising from tangled family affairs and allegations that one of the victims was killed because he was co-operating with the police. The Court of Appeal, relying on the two above cases, held that the leaving of an unedited and uncorrected copy of s. 229(c) was a fatal error requiring a new murder trial. Justice Richard cited Martineau for the proposition that "[s]ince liability for murder must be based on a subjective mens rea, it follows that words ‘ought to have known' in s. 229(c), which import an objective mens rea, are of no force or effect." 41

As in the other cases, the New Brunswick Court of Appeal found that it was impossible to exclude the possibility that the jury might have relied on s. 229(c) as written. This conclusion was reached even though the judge had not specifically instructed the jury on the section and had left the jury with other irrelevant homicide provisions, such as infanticide. A new trial was also ordered even though the jury returned a manslaughter verdict in relation to the victim who was alleged by the Crown to have been killed while the accused was pursuing the unlawful object of intimidating him to no longer co-operate with the police.

Winmill is consistent with the idea that s. 229(c) is making a comeback because the New Brunswick Court of Appeal ruled that the trial judge had erred in not instructing the jury that s. 229(c) was a possible basis for a murder verdict on the evidence, which involved taking the victim to a makeshift grave in a wooded area for the unlawful object of intimidating him from testifying in an upcoming court case in circumstances where the accused may have known that "it was likely he would be killed."42 Although Ms. Charlene Winmill was only convicted of manslaughter, she will face the possibility of a murder conviction under s. 229(c) on her retrial. If the jury is given copies of the Criminal Code at this new trial, they should be properly edited to remove the unconstitutional objective arm. The more interesting issue, however, is whether the use of s. 229(c) will blur the critical distinction between murder and manslaughter especially if it is accepted by the new jury that Winmill did not have the requisite intent under s. 229(a) to kill or harm the intended victim. the trial judge erred by instructing the jury on the objective arm of s. 229(c), see R. v. Ménard, [1998] 2 S.C.R. 109. 


\section{The ReVival OF SECTION 229(C)}

The New Brunswick Court of Appeal's 2008 decision in Winmill is part of a growing revival of s. 229(c). The Ontario courts have been the most active in this regard with the Ontario Court of Appeal deciding several important cases affirming the continuing role of s. 229(c) minus its objective $\operatorname{arm}^{43}$ and courts in other provinces are also making increased resort to the section.

\section{A. R. V. MEILER}

The revival of s. 229(c) can be traced to the 1999 decision of the Ontario Court of Appeal in Meiler. ${ }^{44}$ In that case, the accused formed the intent and the unlawful objective to kill his estranged wife's lover, and to that end entered a backyard barbecue with a cocked and loaded shotgun. There was a dispute about the evidence, but on the version most favourable to the accused, he was tackled from behind and went flying into another guest who stood between him and his intended victim, and the gun unintentionally discharged killing the guest. ${ }^{45}$ The accused was convicted of murder under s. 229(c), and his conviction was upheld on appeal.

The Court of Appeal first outlined the broad actus reus of the section, which requires a person to do anything that causes death to a human being. The act that causes death need not be unlawful and the actus reus requirement that the act cause death was interpreted as requiring the same causation test that is required under s. 222(5). ${ }^{46}$ Associate Chief Justice O’Connor then succinctly described the first mens rea requirement of s. 229(c) as an unlawful object that is "a different object than the assault upon the deceased that gives rise to the charge under s. 229(c)." Consistent with Vasil, the unlawful object would in itself have to be an indictable offence requiring mens rea. This case properly affirms the importance of the distinct unlawful object requirement. On the facts, the accused's object of killing his wife's lover satisfied this requirement, and the Court specifically rejected the idea that the section required "an intent or object to assault or kill the deceased ... if such an object or purpose is present, the case will almost invariably come within either s. 229(a)(i) or (ii) and it would be unnecessary to consider s. 229(c) as a basis for liability. Section 229(c) applies notwithstanding that the offender may not wish to cause injury or death to any one." 48 This conclusion demonstrates a proper approach to statutory interpretation that attempts to attribute distinct meanings to each form of murder contemplated under s. 229.

The Court of Appeal then went on to describe the second mens rea requirement of s. 229(c) as "subjective foresight of death by the offender." 49 Associate Chief Justice O'Connor rejected the idea that the section required "that an offender foresee the precise situation or all of the events that result in the death. It is sufficient if the offender has the subjective foresight that the acts done for the unlawful object are likely to cause death and those acts are sufficiently linked to the

J.S.R., supra note 8.

R. v. Meiler (1999), 136 C.C.C. (3d) 11 (Ont. C.A.) [Meiler].

Ibid. at paras. 17-18.

Ibid. at para. 4. Justice O’Connor described the actus reus requirement as when the offender "does anything .... and thereby causes the death of a human being” (ibid.). The language of the section does not require that the act of the offender be itself unlawful, although because it causes death it will almost inevitably be a dangerous act and will usually be unlawful. See also Vasil, supra note 7 at 482. Meiler, ibid. at para. 48.

Ibid. at para. 51 .

Ibid. at para. 53 . 
death to have caused the death within the meaning of the section." ${ }^{\text {"50 }}$ On the facts of the case, it was sufficient that the accused knew someone would die as a result of his entry into the backyard with a cocked and loaded shotgun. It was not necessary that the accused know that the death would be caused by the perhaps unforeseen circumstance of someone tackling him from behind and the gun accidentally discharging and killing a bystander.

The Court of Appeal rejected the argument that this reading of s. 229(c) expanded the offence of murder beyond its legitimate purview when it stated:

\begin{abstract}
The moral blameworthiness of an offender who does certain acts for an unlawful object knowing that those acts are likely to cause death to someone other than the subject of the unlawful object is no less serious because the offender does not foresee the very situation or the precise circumstances that ultimately lead to that death. It seems to me that the moral blameworthiness at which s. 229(c) is directed results from the decision of an offender to pursue the unlawful object notwithstanding he knows that his acts in doing so will likely cause a death and those same acts do in fact cause a death. An interpretation requiring subjective foresight of the precise manner in which the death is caused would, in my view, unduly restrict the application of the section. ${ }^{51}$
\end{abstract}

The Court of Appeal then went on to note that the Supreme Court, in a 1942 decision in Hughes, had accepted an earlier statement by the Court in 1913 that a predecessor to s. 229(c) would apply in "any situation likely to cause the death of some person — the person killed or any other person." ${ }^{2}$ The reliance on these pre-Charter cases, however, raises some troubling issues. The 1942 case of Hughes involved a struggle during an armed robbery. The Supreme Court relied on the objective arm which, of course, is no longer constitutionally valid. ${ }^{53}$ Moreover, and as discussed above, the Court indicated that manslaughter as opposed to murder should apply if the jury accepted or had a reasonable doubt that the gun went off accidentally. ${ }^{54}$ This latter statement is unfortunately not discussed in Meiler even though it would be relevant on the version of the facts of the case that are most favourable to the accused and suggest that the gun may have discharged accidentally after Mr. Meiler was tackled from behind.

In a critical case comment, Professor R.J. Delisle observed that a result of Meiler, "[i]f the accused is pursuing an unlawful object, and does anything that results in death to someone, even though the actual cause of death is accidental he is guilty of murder. This seems perilously close to the former constructive murder category in s. 230 struck down in R. v. Vaillancourt and R. $v$.

Ibid. at para. 58 .

Ibid. at para. 61 .

Ibid. at para. 62, citing Graves, supra note 21 at 583, as adopted in Hughes, supra note 20 at 522. Hughes, ibid. The Court stated:

I think the act of Yoshyuki in attempting to disarm Hughes and the ensuing struggle were so clearly the natural and ordinary consequences of Hughes' conduct that the jury might well, as reasonable men, have inferred that Hughes ought to have anticipated some such occurrence and the probable involuntary discharge of the pistol as a natural incident of the occurrence; it would then be for them to say whether the conditions of clause $(d)$ of section 259 when read with subsection (2) of section 252, were fulfilled. The learned trial judge did not put this to the jury explicitly, but possibly it is within the scope of his language.

$54 \quad$ Ibid. at 523 . The Court concluded: "If the pistol went off accidentally, in the sense mentioned above, it could hardly be said as matter of law to be an act of violence done by the accused "in furtherance of or in the course of' the crime of robbery.” The Court also seemed concerned about punishing the accused for murder in the 1913 case of Graves, when it quashed a conviction because the trial judge had not made clear that the jury must conclude that the death was a probable consequence of the accused's actions of assaulting a person who had a loaded gun. 
Martineau." ${ }^{55}$ Following in the vein of Professor Delisle's criticisms, the facts of Meiler are not all that different than the facts of Vaillancourt, in which the Supreme Court invalidated the most notorious form of constructive murder for committing a robbery with a firearm on the basis that the Criminal Code did not even require proof of objective foresight of death and could be applied to accidental killings. ${ }^{56}$ Indeed, s. 229(c) would in some respects be even broader than s. 230 because it would apply to any unlawful object that constituted a mens rea offence punishable by indictment whereas the constructive murder provision only applied to specifically listed serious crimes.

Even leaving aside the danger that s. 229(c) could cover killings that would previously have been constructive murder, there is an equal danger that the section could apply to killings that would normally be unlawful act manslaughters. The Ontario Court of Appeal in Meiler did not confront the fact that the Supreme Court, in the 1942 case of Hughes, expressed the view that the predecessor of s. 229(c) should not apply if a gun discharged accidentally during a robbery. ${ }^{57} \mathrm{It}$ is difficult to distinguish such a scenario from what occurred in Meiler at least if the accused's testimony is accepted. In both cases, the accused had unlawful objects (killing his wife's lover in Meiler and robbery in Hughes), but in both cases it seems wrong and disproportionate that an accidental discharge of a firearm should result in a murder conviction. Of course, the matter would be different if the jury had concluded that Meiler had deliberately shot the victim who stood between him and his intended victim. On such a scenario, however, it is difficult to understand why s. 229(a) or perhaps s. 229(b) should not apply.

But there is a possible rejoinder to the critique of Meiler as a revival of constructive murder or a conversion of accidental unlawful act manslaughter into murder. Although the unlawful object requirement of s. 229(c) may not be all that different from the requirement of the commission of an underlying offence in s. 230 or the requirement for an unlawful act under s. 222(5)(a), s. 229(c) after Martineau and as interpreted in Meiler requires the Crown to prove that the accused subjectively knew that his or her actions were likely to cause death. In other words, the second mens rea requirement of s. 229(c), the requirement that the accused know that a death is likely to occur in the pursuit of an unlawful object, is the critical doctrinal distinction and one that is necessary to protect s. 229(c) from a Charter challenge. Before too much weight is accorded to this distinction, however, it is important to have a deeper understanding of what it means to conclude that an accused knew that someone was likely to die under s. 229(c) and how that form of guilty knowledge may differ from the guilty knowledge required under ss. 229(a) and (b), both of which require that the accused either intend to cause the death of particular victims or intend to cause them bodily harm knowing that they are likely to die.

The actual meaning of subjective knowledge of death is surprisingly underdeveloped given its foundational and constitutional status in our law of murder. Even on the facts of Meiler, the precise meaning of this critical requirement is unclear. It could easily be satisfied if the jury accepted the testimony of two witnesses who testified that they saw the accused shoot the victim

\footnotetext{
$55 \quad$ R.J. Delisle, “Unlawful Object Murder is Alive and Well” (1999) 25 C.R. (5th) 179 at 180 [footnotes omitted]. Vaillancourt, supra note 1. Meiler, supra note 44.
} 
who was between the accused and his intended victim. ${ }^{58}$ On the other hand, the meaning of subjective knowledge of the likelihood of death would be much more flexible, broad, and less demanding if the jury accepted the accused's testimony that the gun accidentally discharged after he was tackled from behind. ${ }^{59}$

The precise meaning of subjective knowledge of the likelihood of death is also particularly important in cases unlike Meiler where there is no intended murder victim and an accused simply pursues a dangerous and unlawful object. These are the most difficult cases, and they raise the question of the precise meaning of subjective foresight of death, the limits of murder liability, and the respective roles of murder and manslaughter in punishing unlawful homicides.

\section{B. SUBJECTIVE FORESIGHT OF DEATH IN SECTION 229(C): WHAT DOES IT REALLY REQUIRE?}

The danger of maintaining the form of subjective fault, while undermining much of its content is well illustrated in two Ontario cases that arose from the same spectacular six alarm fire in Toronto that was set by arson. The badly burned body of one of the people involved in setting the fire was eventually discovered on the premises. The owners of the burned building were prosecuted for murder for his death as were some of his other accomplices in the arson. In both cases, the Crown relied on s. 229(c).

\section{The Toronto Arson CASES}

In Magno, ${ }^{60}$ the Ontario Court of Appeal held that a preliminary inquiry judge had erred in not committing an accused for trial under s. 229(c). The judge at the preliminary hearing had held that there was no evidence of subjective intent to justify a committal on the murder offence. The Ontario Court of Appeal reversed with Gillese J.A. stating that while the inquiry under s. 229(c)

is ultimately a subjective one ... [t]he fact that a reasonable person would have foreseen the likelihood of death makes available the inference that the appellants, as reasonable persons, would have foreseen the likelihood of death. By failing to consider the possibility that this inference was available, the preliminary inquiry judge failed to consider the inference favourable to the Crown and considered only the inference that favoured the appellants. $^{61}$

Ibid. at paras. 15-16. The testimony of these two witnesses is summarized as follows:

Patti Skrinjaric testified that she was in the backyard when she heard a crash. She ran down the side of the house towards the roadway. The appellant was charging towards her with something in his hand and knocked her into the hedge. She looked towards the gate and saw the appellant in one motion raise his arm and a gun shot went off. Immediately after, she saw her husband on the ground wrestling with the appellant. Vlad Skrinjaric testified that he was also in the backyard when he heard a loud bang coming from the direction of the front of the house. He followed his wife who ran down the side of the house towards the road and on reaching the driveway he saw the appellant heading towards her. The appellant ran by Patti Skrinjaric and shoved her into the hedge. As Vlad Skrinjaric ran towards the appellant, he saw a blue flame by the appellant's side. He then jumped on the appellant, wrestled him to the ground and in the ensuing struggle took the gun away from him. The appellant got up and ran away. 
This line of reasoning, if applied at trial, could tempt triers of fact to jump from the issue of whether a reasonable person would have foreseen the likelihood of death to a conclusion that the accused actually did have such foresight. ${ }^{62}$ Although such reasoning from what a reasonable person would have recognized is not impermissible, it runs the risk of blurring the fundamental distinctions between subjective and objective fault. ${ }^{63}$ This is a particular danger in cases where the accused is doing something, such as arson, that the trier of fact would never do.

Magno opens up the real possibility that accidental deaths in the pursuit of blameworthy unlawful objects will be characterized as murders under s. 229(c). It goes beyond Meiler because in Meiler the accused had at least formed an intent to kill a person and, in pursuing that intent, unexpectedly and accidentally killed another. In Magno, it is readily accepted that none of the participants intended to kill or harm any person. To be sure, this does not render them innocent, and they would likely be guilty of manslaughter for the dangerous pursuit of an unlawful object that resulted in death. The conclusion that they can be convicted of murder for an accidental death, however, is troubling. As will be suggested, it arguably violates a principle of fundamental justice that a person should not be punished as a murderer for accidental deaths.

In another case, Roks, arising from the same deadly arson in Toronto, Epstein J. of the Ontario Superior Court in a judge alone trial held that a participant to the arson was guilty of murder under s. 229(c). Justice Epstein held that, in light of Meiler, "if neither the precise situation nor the specific individual harmed need be foreseeable, the fact that the individual ultimately harmed is a participant as opposed to an innocent bystander should not be relevant to a determination of culpability." ${ }^{4}$ There was no doubt that the accused "did not intend to cause harm or death to any individual. In fact, during the planning process, the co-conspirators took precautions.”65 Nevertheless, "[t]hese precautions do not, however, rebut the subjective foresight of harm requirement. On the contrary, they can be considered to support it; had there been no awareness that the plan was dangerous, it is less likely that precautions would have been taken."66 The judge then noted the circumstances of the arson and concluded:

\footnotetext{
Under these circumstances, the likelihood of harm or death was clearly foreseeable. Whether the person harmed would be the one to set the fire, a resident of an adjacent building, or a firefighter called to the scene, is irrelevant for the purposes of s. 229(c). As already noted above, Meiler clearly supports the proposition that neither the precise situation nor the specific individual harmed need be foreseeable. It is sufficient to prove subjective forseeability of harm to anyone. A normal or reasonable person would have foreseen this likelihood of harm.
}

I am therefore satisfied beyond a reasonable doubt that the mens rea requirements of s. 229(c) are met in this case: Roks knowingly conspired and assisted in the unlawful object of arson for the purpose of insurance fraud; instructions that urge jurors "as a matter of common sense to draw an inference that a sane and sober person knows the natural and probable consequences of his or her voluntary actions” (ibid.). The jury instruction is somewhat mitigated by a reference that the jury is not required to draw such inferences and should consider all the circumstances of the case including what the accused said and did.

R. v. Buzzanga (1979), 25 O.R. (2d) 705 (C.A.); Pappajohn v. R., [1980] 2 S.C.R. 120.

R. v. Roks (2007), 74 W.C.B. (2d) 318 at para. 253 (Ont. Sup. Ct. J.) [Roks].

Ibid. at para. 258.

Ibid. 
I am also satisfied that he possessed subjective knowledge that harm or death was a likely outcome of the fire.

Anthony Jarcevic died as a result of the fire. ${ }^{67}$

In this passage, the group of foreseeable victims is defined very broadly to include fellow perpetrators of the crime, residents adjacent to the building, and even firefighters who might subsequently battle the blaze. This comes close to defining the group of potential victims as the world at large. It even raises the question of whether the accused would have been found guilty for a death of a person, such as a homeless person, secretly living in the building who was not known or even knowable to the accused. Such a scenario underlines the danger of extending s. 229(c) into the realm of unlawful act manslaughter.

Another danger in Roks is the slippage that occurs in the judgment between the requirement under both s. 229(c) and Martineau that the accused must know that death is likely to occur and the less onerous fault requirement of recklessness or subjective advertence to the possibility of death. For example, the trial judge found that the accused "did not mean to hurt anyone, Roks risked human life for money. This risk materialized and greed and incompetence ended in tragedy." ${ }^{68}$ The concept of risk is more associated with negligence or recklessness in the form of subjective advertence to the risk or possibility of the prohibited act occurring as opposed to knowledge of the likelihood or probabilities of the prohibited act occurring. ${ }^{69}$

Knowledge of the risk of harm is another way of describing recklessness to the possibility of death. In contrast, the constitutionally required mens rea for murder is knowledge of the probability of death. The Supreme Court in both Nygaard $^{70}$ and Cooper $^{71}$ has stressed that the reference to recklessness in s. 229(a)(ii) is a redundant afterthought, and the Ontario Court of Appeal has likewise stressed that references to the risk or chance of death are not sufficient under s. 229(a)(ii). ${ }^{72}$ If references to risks or chances are not sufficient under s. 229(a)(ii), they should not be sufficient under s. 229(c) both because of the requirement in s. 229(c) of subjective knowledge of the likelihood of death and the similar constitutional requirement in Martineau. The requirement of knowledge of the likelihood or probability of death as opposed to advertence to the risk or possibility of death is of critical importance in s. 229(c). Both the statute and the constitutional requirements of Martineau demand proof of the higher knowledge requirement and courts should be careful to ensure that the mens rea for s. 229(c) is not downgraded to recklessness or subjective awareness of the risk or possibility of death.

In addition to the above problems with respect to the broad and indeterminate definition of potential victims and the use of risk language associated with recklessness, Roks also strains the distinctions between objective and subjective fault. In this judge alone trial, the judge, as was indeed contemplated by the Court of Appeal's related decision in Magno, moved rather quickly from the common sense proposition that a reasonable person would and should have recognized

Ibid. at paras. 263-64 [emphasis added].

Ibid. at para. 270 [emphasis added].

Ibid. at para. 269 (the trial judge also concluded that "death was foreseeable and that Roks foresaw its likelihood and proceeded despite an awareness of this risk"). Although this passage makes appropriate reference to the likelihood of death, the force of this reference is undermined by the reference to "awareness of this risk," which suggests subjective advertence to something less than a likelihood or probability of death.

Supra note 11.

Supra note 24.

Czibulka, supra note 27 at paras. 62-70; Patterson, supra note 27 at paras. 34-48. 
foreseeability of death when pursuing dangerous unlawful objects to a conclusion that the accused in fact did foresee such harm even though he had no intent "to hurt anyone."73 The conclusion that Mr. Roks had subjective foresight of death is not satisfying because it relies so heavily on the notion that the accused would have the insights that a reasonable person would have in the circumstances. The reasonable person, of course, would never commit an arson during the dead of the night.

Roks is a much more problematic decision than Meiler where the accused at least intended to kill someone. It seems disproportionate to impose the stigma and punishment of a murderer on a person who had no intent to harm anyone and who may only have been reckless in the form of adverting to the risk or possibility that a large group of people might possibly die as a result of the conduct of the unlawful object. It also offends the principle of fundamental justice that those who cause harm intentionally should be punished more severely than those who cause harm unintentionally. ${ }^{74}$ Roks demonstrates how s. 229(c) can be expanded into territory that should be reserved for manslaughter.

\section{An UNNECESSARY USE OF SECTION 229(C) IN MANITOBA}

A similar expansive approach to what constitutes subjective foresight of death can be found in Côté, a 2007 trial from Manitoba. ${ }^{75}$ The case involved a convenience store robber who fired five shots at and fatally wounded a store owner who had retaliated to the robbery attempt with a baseball bat. In the absence of self-defence or provocation claims (both of which were rejected), it might have been thought that this case should have proceeded under s. 229(a) on the basis that the accused intended to harm the owner knowing that his shots would likely cause the owner's death. Nevertheless, the murder charge in this judge alone trial was brought under s. 229(c). This case suggests that prosecutors may now be more willing to use s. 229(c). This strategy is not without dangers, especially in cases such as Côté where other more direct strategies are available. One danger for both prosecutors and judges at preliminary inquiries is that the constitutionality of s. 229(c) minus its objective arm has yet to be resolved. Another danger is that jurisprudence surrounding proof of a distinct unlawful object as well as the precise meaning of knowledge that acts are likely to cause death are complex and thus error prone. In cases like Roks, no other murder charge other than s. 229(c) may be possible, but prudent prosecutors should avoid a contentious s. 229(c) charge if they have evidence to support a more straightforward use of either ss. 229(a) or (b).

Côté follows the trend in the Toronto arson cases discussed above because the judge related the accused's mens rea under s. 229(c) to his actions in robbing a store with a loaded weapon as opposed to his more immediate actions in firing multiple shots at the victim. Justice Keyser stated that

[i]t matters not that Côté wished to effect his object without causing death or bodily harm to anyone.... [T]he very fact of bringing a loaded weapon to rob a store is real evidence that Côté had to have had subjective foresight of the likelihood of death or grievous bodily harm if he used the weapon during the robbery, or even

Roks, supra note 64 at para. 270.

Creighton, supra note 6. See Part VII.C, below.

R. v. Côté, 2007 MBQB 36, 211 Man. R. (2d) 312 [Côté]. 
if it accidentally discharged. Further, he ended up firing four shots at Yue, at least two of which connected with Yue's head. ${ }^{76}$

To be sure, a focus on the unlawful objective is necessary to satisfy one of the mens rea requirements of s. 229(c). In making such determinations, courts should apply the leading decision of Vasil discussed above. Nevertheless, proof of pursuit of an unlawful object that is distinct from the immediate object of the dangerous act is only one of two mens rea requirements in s. 229(c).

The second mens rea requirement under s. 229(c) is proof of knowledge of death. It is by far the more important of the two mens rea requirements because Martineau affirms that knowledge of the likelihood of death is constitutionally required. The focus in Côté on the unlawful and dangerous object of robbery comes perilously close to the old constructive liability theory based on the commission of a robbery with a gun. This is especially the case if, following the Ontario Court of Appeal in Magno, one places considerable reliance on the idea that one can infer subjective intent from the existence of reasonable foresight of death.

A broad and abstract approach to what constitutes subjective foresight of death also runs the risk of blurring distinctions between recklessness towards the risk or possibility of death and knowledge of the likelihood or probability of death. This is especially the case if the victim is, as in Roks, only one of a large group of people who are exposed to the risk or danger that follows from the pursuit of a dangerous unlawful object.

Finally, courts should not forget that the second mens rea requirement of knowledge of the likelihood of death should be determined at the time of the commission of the actus reus of causing death. The issue should not be whether a reasonable person or even the accused should or would have recognized the risk of a death when they embarked on their unlawful object. Rather, the focus should be on whether the accused subjectively knew that there was a likelihood of death at the time that death was caused while committing unlawful objects such as robberies and arsons.

\section{E. R. V. J.S.R. A.K.A. THE JANE CREBA CASE}

The most notable recent case of the use of s. 229(c) arose out of the shooting death of Jane Creba, a bystander who was killed when a gun battle broke out on a busy shopping section of Yonge Street in Toronto on Boxing Day, 2005. The Crown has charged one of the young offenders alleged to have fired shots with murder under both ss. 229(b) and (c) of the Criminal Code.

\section{COMMITTAL PROCEEDINGS}

The committal for murder under these sections by the preliminary inquiry judge was quashed on the basis that there was no evidence to support a murder charge. In July 2008, a three judge panel of the Ontario Court of Appeal composed of Doherty, Moldaver, and Watt JJ.A. allowed the Crown's appeal and restored the murder charge under s. 229(c), but not under s. 229(b). Both 
because of the notoriety of the case and the vast criminal law expertise of the panel in this case, the Ontario Court of Appeal's decision in J.S.R. ${ }^{77}$ may become an important precedent that will encourage increased use of s. 229(c).

After a close examination of Meiler, which accepted that s. 229(c) would apply to even accidental deaths in the pursuit of an unlawful object, ${ }^{78}$ the Court of Appeal in J.S.R. concluded:

In the case at hand, J.S.R. intended no harm to Ms. Creba. She was not the target of his unlawful object — the northbound shooter was. In carrying out his unlawful object, J.S.R. engaged in a dangerous act — a frenzied shootout in which he fired his gun numerous times into a crowded street teeming with people. Leaving aside any defences that might be available to him, by engaging in the shootout, J.S.R. had to know that someone other than the northbound shooter was likely to die.

On those facts, we are satisfied that J.S.R. comes within the parameters of s. 229(c). Manifestly, in our view, if proved, his conduct would meet the high degree of moral blameworthiness needed to justify the stigma of a murder conviction and the consequences flowing from it. ${ }^{79}$

The Court of Appeal required that the accused have an unlawful object distinct from that which led to the victim's death even though it concluded that such a requirement had traditionally been related to the need to restrict the availability of the objective arm of s. 229(c), a theory of liability that is no longer available after Martineau. ${ }^{80}$ As suggested above, the requirement for an independent unlawful object is necessary to ensure that s. 229(c) does not eclipse the other murder provisions of s. 229. The facts of this case did not require the Court of Appeal to resolve the tensions between the pre-Charter precedents of Tennant and DeWolfe. There may, however, be a temptation to favour the less onerous approach contemplated in Tennant if the Court of Appeal believes that the distinct unlawful object requirement was mainly designed to restrain the oft-criticized and now unconstitutional objective arm of s. 229(c). As suggested above, this would be unfortunate given the need to ensure that s. 229(c) does not eclipse the other murder provisions in s. 229.

The Court of Appeal found that a committal on murder under s. 229(b) was not warranted. It stressed that the accused

did nothing “by accident or mistake” that caused or materially contributed to Ms. Creba’s death. On the Crown's theory, J.S.R. caused Ms. Creba's death by engaging in a mutual gun battle on a crowded street. That is exactly what he set out to do. On this view of J.S.R.'s causal responsibility, there was nothing he did "by accident or mistake” that materially contributed to Ms. Creba's death. ${ }^{81}$

This conclusion is based on a restrictive and non-purposive reading of the reference in s. 229(b) to the killing of another person by accident in circumstances where an accused has formed the intent to kill or to cause bodily harm to another knowing that the harm will likely cause the

$77 \quad$ Supra note 8.

78 Ibid. at paras. 52, 59. As discussed above, there was a conflict of evidence in Meiler, but the Court of Appeal in J.S.R. seemed to accept the evidence provided by the accused in that case, which suggested that the gun discharged accidentally after he was tackled.

79 J.S.R., ibid. at paras. 65-66.

80 Ibid. at paras. 63-64.

$81 \quad$ Ibid. at para. 38. 
victim's death. The Court of Appeal's restrictive reading of s. 229(b) fails to recognize that the blameworthiness of the accused in both this case and in Meiler was increased by the fact that they had the intent to kill someone, albeit not the actual victim. In contrast, in the Toronto arson cases of Magno and Roks, the accused did not intend to kill or even to harm any person. If the facts alleged by the Crown in J.S.R. are proven, and leaving aside the causation issue that is raised by the fact that none of the accused's multiple shots killed Ms. Creba, this case is a stronger case for murder than those in which the accused neither intended to kill or harm any person while admittedly carrying out a dangerous unlawful object in a manner that caused death.

\section{THE CHARTER RULING}

A few months after the Court of Appeal's rulings, Nordheimer J. considered a Charter challenge by the accused in J.S.R. to s. 229(c). ${ }^{82}$ Noting that, in Martineau, Lamer C.J.C. concluded that because of its stigma and punishment, "a murder conviction must be reserved for those who either intend to cause death or who intend to cause bodily harm that they know will likely cause death," ${ }^{83}$ Nordheimer J. stated that "[t]aken by itself, this statement would appear to require an intent for the offence of murder that is missing from s. 229(c). It is unclear, however, whether that conclusion can be fairly drawn from the case given that the Supreme Court was not addressing the constitutional validity of s. 229(c) as a whole." ${ }^{84}$ This finding underlines the need for the Supreme Court to clarify the precise mens rea that is constitutionally required for murder by considering s. 229(c) on its own merits. Justice Nordheimer stressed that the Ontario Court of Appeal in both Meiler and J.S.R. had proceeded on the basis that the moral blameworthiness of an unlawful object and subjective knowledge of the likelihood of death required under s. 229(c) would be constitutionally sufficient. In both of these cases, however, the Court of Appeal did not provide a consideration of the full issue of constitutionality. ${ }^{85}$ Justice Nordheimer gave considerable weight to the fact that neither the Supreme Court nor the Ontario Court of Appeal had expressed any concerns about the constitutional validity of s. 229(c) once the objective arm of the section was expunged. ${ }^{86}$ Although such deference by a trial judge is understandable, reliance on these cases is problematic because in none of them was the constitutional validity of the remaining parts of s. 229(c) directly raised.

The constitutionality of s. 229(c) should not be resolved on prior authority. It requires careful and fresh consideration. On the merits, Nordheimer J. upheld the constitutional validity of s. 229(c). Nevertheless, he candidly admitted that his conclusion

is not without its doubts. I have reached that conclusion for two main reasons. First, I see no principled reason for not characterizing actions of an individual undertaken for an unlawful purpose, in circumstances where the individual knows that those actions are likely to result in the death of a person, as murder. If a person undertakes a dangerous and unlawful act knowing that someone is likely to be killed, I do not see any reason why that

R. v. J.S.R., [2008] O.J. No. 4162 (Sup. Ct. J.) (QL) [J.S.R. Sup. Ct.].

Martineau, supra note 1 at 646. See also Creighton, supra note 6 at 54, McLachlin J.: "Just as it would offend fundamental justice to punish a person who did not intend to kill for murder, so it would equally offend common notions of justice to acquit a person who has killed another of manslaughter and find him guilty instead of aggravated assault on the ground that death, as opposed to harm, was not foreseeable."

J.S.R. Sup. Ct., supra note 82 at para. 13.

Ibid. at paras. 17-18.

Ibid. at para. 29. 
conduct should not attract the stigma of the offence of murder even though the person does not wish anyone to be killed. The degree of moral blameworthiness that attaches to a direct plan to kill and that which attaches to an unlawful plan where death is more likely than not to occur, even if death is not desired, is not so different that constituting the latter along with the former as murder should offend any principle of fundamental justice. The following example ... captures the essential point:

For practical purposes we can make no distinction between a man who shoots another through the head, expressly meaning to kill him ... and a man who, intending for some object of his own, to stop the passage of a railway train, contrives an explosion of gunpowder or dynamite under the engine, hoping indeed that death may not be caused, but determined to effect his purpose whether it is so caused or not. ${ }^{87}$

This quote, however, is taken from statements by the Imperial Commissioners who prepared a draft Code that inspired the Canadian Criminal $\operatorname{Code}^{88}$ and it would be surprising if such statements were determinative of the constitutionality of s. 229(c). Even in the pre-Charter case of Vasil, ${ }^{89}$ the Supreme Court was reluctant to place too much reliance on the above quote. As Nordheimer J. recognized, the constitutionality of s. 229(c) even minus its objective arm is a difficult one that seems destined for more "protracted analysis that might be better undertaken at another time and in another forum.,

\section{What is TO BE Done About Section 229(C)?}

The simplest solution would have been if the Court had used Martineau to strike down s. 229(c) in its entirety or if Parliament had simply repealed the section. There is no evidence that the failure to use s. 229(c) between Martineau and its most recent revival threatened social protection. ${ }^{91}$ Cases like Meiler and J.S.R., where the accused formed an intent to kill one person but killed another person, could be dealt with under the transferred intent provisions of s. 229(b). The scenario of a person planting a bomb on a train or in a public place requires more facts, but could possibly fall under s. 229(a) in cases where there is a known class of victims. If an intent to kill or harm specific victims is absent, then unlawful act manslaughter would apply and high sentences could be given to recognize the danger of using bombs. That said, it is unlikely that Parliament will ever repeal s. 229(c). The same Parliamentary inertia that has prevented the formal repeal of the objective arm of s. 229(c) will likely prevent the repeal of s. 229(c).

\section{A. Clarifying What "SubJECTIVE Foresight OF DEATH” ACtUALly MeANS}

The Supreme Court should clarify the constitutionally required fault element for murder. In Martineau and its companion cases, the Court sometimes described the constitutionally required

Ibid. at para. 28.

As reproduced in J.C. Martin, ed., Martin’s Annual Criminal Code, 1st ed. (Toronto: Canada Law Book, 1955) at 385.

Vasil, supra note 7 at 488-89. In that case, Lamer J. observed that the observations of the Imperial Commissioners should not be taken as support for a broad reading of the unlawful object requirement because "in 1878 unlawfully obstructing a railway train was very serious, was punishable by two years at hard labour, and, if done maliciously (i.e. an act done mischievously, with an intention to obstruct but without the intention of causing injury, could be malicious) was then a felony punishable by life imprisonment" [footnotes omitted].

J.S.R. Sup. Ct., supra note 82 at para. 32. The accused was convicted of second degree murder and has been sentenced as an adult.

Stuart, supra note 17 at 208-11. 
mens rea of murder by the shorthand "subjective foresight of death."92 Although shorthand phrases are convenient, they can be misleading especially when used with respect to something as important as murder. As suggested above, a better description of the constitutionally required fault for murder is subjective knowledge of the likelihood or probability of death. This fault requirement is higher than subjective recklessness and the Court should explain why reckless murder is constitutionally insufficient. In other words, the Court should explain why the special stigma and penalty of a murder conviction should be reserved for those who have knowledge of the probability of death as opposed to those who only advert to the possibility of death. Even if this understanding of Martineau is confirmed and reckless murder is rejected, the Court should address how broad and indeterminate the potential group of victims that the accused knows is likely to die can become before the constitutionally required knowledge requirement is eroded past the constitutional limit. Finally, the Court should address whether it is constitutional to impose a murder conviction for an accidental death that occurs in the pursuit of a dangerous unlawful object when the accused does not have the intent to harm or kill anyone.

One possible approach would be for the Court to decide that subjective foresight of death to a broad and indeterminate group of potential victims is not a sufficient form of fault given the stigma and penalty of a murder conviction. If the group of potential victims includes everyone that a reasonable person could foresee might be harmed, then it is not very meaningful to conclude that the accused has murdered the person who eventually dies. Moreover, it is difficult to maintain that the accused knew that a wide range of victims would likely die. It is more accurate to say that the accused knew that it was possible that such a large range of victims would die or that the accused should have known that someone would die. Foresight of death to indeterminate victims is a less meaningful and onerous fault requirement than the fault requirement in s. 229(a) of knowledge of the likelihood of the victim's death or even the requirement in s. 229(b) of knowledge of the likelihood of a third party's death. To be sure, s. 229(c) retains the form of the constitutional requirement of knowledge of death, and it satisfies casual or shorthand descriptions of the fault requirement. Nevertheless, a good deal of the substance of the fault requirement of knowledge of the likelihood of death is drained away by the non-particularized nature of the danger and range of potential victims. Indeed, there may be a temptation for prosecutors to argue, and for juries to accept, that whenever firearms or other dangerous substances are used that somebody could die. Such an approach would be closer to recklessness towards the risk or possibility of death or even objective foresight of the causing of death than the constitutionally required mens rea of knowledge of the likelihood of death. Indeed, a focus on the dangerous nature of the unlawful objective runs a risk of imposing constructive liability as was done under the former s. 230 of the Criminal Code and under unlawful act manslaughter. There will be a temptation for juries and perhaps even judges to reason back from the fact that death was in fact caused in the pursuit of the unlawful object and to focus on the dangerous and invidious nature of the unlawful object as opposed to the guilty knowledge that the accused actually possessed at the moment that death was caused. The watering down of the constitutionally required mens rea of knowledge of the likelihood of death will result in jurisprudence that, like the pre-Charter jurisprudence, will be dominated by the first mens rea requirement of a distinct unlawful object at the expense of the now constitutionally required mens rea of subjective knowledge of the likelihood of death. 
Judges should be encouraged to instruct juries that, under s. 229(c), the prosecutor must prove beyond a reasonable doubt that the accused knew that some foreseeable number of people would die as a result of the carrying out of the unlawful object even though the accused may not have desired for such deaths to occur. The purpose of articulating a specific range of victims will be to force the trier of fact to determine whether the accused knew that such victims would probably die or whether the accused had lesser forms of fault, including reckless advertence to the possibility of death. If the accused was only reckless and did not know that the group of potential victims of which the actual victim was a member would likely die, then the mens rea for s. 229(c) would not be established. The text of s. 229(c) and the constitutionally required mens rea of knowledge of the likelihood of death require no less.

\section{B. ACCidental Deaths Should not Be Punished As Murder: A NeW PRinCiPle OF Fundamental Justice}

The criteria for recognizing new principles of fundamental justice are demanding. The principle must be a precise legal principle of long standing and it must be manageable. ${ }^{93}$ Courts have long had grave concerns about convicting someone of murder for an accidental death that occurs during the commission of the pursuit of an unlawful object. Such concerns about imposing murder convictions for truly accidental deaths are at least as old as the 1913 case of Graves $^{94}$ and the 1942 case of Hughes. ${ }^{95}$ There is also a consensus that an accidental death does not merit the special stigma and punishment of murder. The idea that accidental deaths are not murder is a precise and manageable legal principle that relies on judicial expertise and experience in maintaining the vital distinction in the respective stigma and punishment for murder and manslaughter. Courts should be able to determine what deaths are accidental and what deaths are not. As such, the principle that an accidental death does not merit a murder conviction should be recognized as a principle of fundamental justice under s. 7 of the Charter.

The principle that accidental deaths should not be treated as murder will not necessarily result in the invalidation of the rest of s. 229(c), though that would probably be the simplest reform. Rather, the new principle of fundamental justice would supplement the principle recognized in Martineau that subjective knowledge of the likelihood of death is the constitutionally required mens rea for murder. This principle is also supported by basic criminal law principles that the culpability of an individual for causing death should be judged on the accused's fault at the time of the actus reus as opposed to the accused's pre-existing fault at large in the time before the actus reus was committed. ${ }^{96}$

\section{Unintentional HaRm SHOUld Not Be PUNiShed AS SEVEREly AS INTENTIONAL HARM: AN EXISTING PRINCIPLE OF FUNDAMENTAL JUSTICE}

To the extent that s. 229(c) punishes unintentional and even accidental killings, it also runs afoul of the established principle of fundamental justice that those who cause harm 
unintentionally should not be punished as severely as those who cause harm intentionally. This principle was recognized in the majority judgment in Creighton where McLachlin J. recognized "the principle that those causing harm intentionally must be punished more severely than those causing harm unintentionally."${ }^{, 97}$ This principle was satisfied in that case because unintentional killings that resulted in manslaughter convictions were treated less severely than the intentional killings that were captured by murder.

Justice McLachlin in Creighton held that the principle of fundamental justice that intentional harm be treated more severely than unintentional harm was derived from Martineau and helped justify the decision to strike down constructive murder provisions. The former constructive murder provisions struck down in Martineau at least required that the accused intend to harm the victim by causing bodily harm. Section 229(c) can and has been applied in cases where the accused pursued a risky and dangerous unlawful object without intending to harm anyone.

The concept of intentional harm in Creighton is in many ways more concrete, meaningful, and determinate than the references in Martineau to subjective foresight of death. The idea that unintentional harm is less serious than harm that is caused intentionally makes intuitive sense. As Oliver Wendall Holmes famously stated, "even a dog distinguishes between being stumbled over and being kicked." 98 The principle that the causing of unintentional harm is less blameworthy than the causing of intentional harm is a manageable and traditional legal principle. It has appropriately been recognized as a principle of fundamental justice. It has been followed by Parliament in its separate creation of negligence offences such as manslaughter and negligent arson. The principle that unintentional harm not be punished as severely as intentional harm also accords with understandings of sentence proportionality and fair labelling that apply across the criminal law. ${ }^{99}$ These concerns are particularly important given the stigma and mandatory penalty that would follow a conviction for murder under s. 229(c). It is difficult to question the proposition that the stigma attached to the causing of unintentional harm is less than that attached to the causing of intentional harm. The principle that unintentional harms not be punished as severely as intentional harms is violated when s. 229(c) applies to accidental deaths, as suggested above. The principle would also be violated if s. 229(c) applies in cases where the death is not classified as accidental, but the accused intended no harm to anyone while pursuing his or her unlawful object.

\section{ClARIFYING THE IMPORTANCE OF SECTION 229(B)}

At the same time as the Court addresses s. 229(c), it could also usefully suggest that s. 229(b) might apply in cases like Meiler or the Creba case where the accused has the intent to kill a specific victim but then accidentally kills another victim. The reluctance to affirm the constitutionality and utility of s. 229(b) in such cases is odd. The courts have interpreted s. 229(b) in a technical fashion despite the Court's admonition to give criminal offences, including murder offences, a purposive interpretation. ${ }^{100}$ It is difficult to understand why the courts have been so reluctant to apply s. 229(b). After all, a person found guilty under s. 229(b) has the same

$97 \quad$ Creighton, supra note 6 at 49.

$98 \quad$ Oliver Wendell Holmes, The Common Law (Boston: Little Brown, 1923) at 3.

$99 \quad$ Stuart, supra note 17 at 215.

100 R. v. Paré, [1987] 2 S.C.R. 618; R. v. Russell, 2001 SCC 53, [2001] 2 S.C.R. 804; Roach, supra note 26 at $79-83$. 
blameworthy intent as a person convicted under s. 229(a), namely the intent to cause bodily harm with knowledge of the likelihood of death to some victim. A more expansive reading of s. 229(b) would mean that, contrary to the Ontario Court of Appeal's ruling in J.S.R., ${ }^{101}$ the provision may apply in cases such as the Jane Creba or Meiler cases where the accused intends to kill one person, but kills another person by accident or mistake. Such an approach would ensure that everyone convicted of murder has the "killer instinct" that warrants the special stigma and punishment of a murder conviction. Section 229(b) has also been appropriately interpreted to not include accidental deaths. ${ }^{102}$

\section{E. Clarifying THE MENS REA REQUiREMENTS OF SECTION 229(C)}

If the Court is not willing to strike down what remains of s. 229(c) or recognize that it is constrained by the principle that accidental deaths should not merit murder convictions or that unintentional harm should not be punished as severely as intentional harm, it will be important for it to clarify and bolster the mens rea requirement for murder in at least two ways. First, the Court should confirm its pre-Charter ruling in Vasil $^{103}$ that the prosecutor must establish some serious unlawful purpose that is distinct from the acts that cause the victim's death. Although this requirement will introduce complexities into the law, they are necessary if s. 229(c) is not to swallow up the other murder provisions and provide prosecutors with an easy end run around the more onerous fault elements of ss. 229(a) and (b). Suggestions that courts should reconsider this requirement and perhaps include negligence and even regulatory offences as unlawful objects ${ }^{104}$ should be resisted for at least two reasons. One is that the inclusion of negligence based offences, such as dangerous driving or criminal negligence causing death, will encourage courts to include as unlawful objects enterprises that are not really distinct from the acts that resulted in the victim's death. The existence of a conspiracy-like distinct unlawful object ${ }^{105}$ provides some additional measure of blameworthiness that can partially address the fact that a person can be convicted of murder under s. 229(c) even though they did not intend to kill or cause bodily harm that they knew was likely to cause death to anyone, let alone any specific person. To be sure, such an approach embraces some of the punitive logic of felony murder, but it is inescapable if s. 229(c) is to remain part of the law.

The second requirement is that the Court should delineate precisely what is meant by references in s. 229(c) and Martineau to subjective foresight of death. The courts should go beyond the shorthand of subjective foresight of death and be as specific as possible about what the prosecutor must prove. One task is to distinguish subjective knowledge of death from the reference in s. 229(c) to the accused being able to have this guilty state of mind without desiring that death or bodily harm be caused to any human being. In this respect, guidance may be found in the Court's decision in R. v. Hibbert, ${ }^{106}$ where it distinguished between knowledge of the crime and the desire that the crime be committed. Another task is, following Meiler, ${ }^{107}$ to make clear

$101 \quad$ Supra note 8.

$102 \quad$ R. v. Droste (1979), 49 C.C.C. (2d) 52 at 54 (Ont. C.A.).

103 Supra note 7.

104 Grant, Chunn \& Boyle, supra note 29 at 4-50.

105 DeWolfe, supra note 7 at 307-308. As Zuber J.A. recognized, "[i]t is noteworthy as well that in both Graves and Tennant and Naccarato the accused persons were parties to a conspiracy or something very close to it. While obviously a conspiracy is not a prerequisite to a further unlawful object, it does serve to underline such an object.” 
that the mens rea of s. 229(c) requires not only proof of the unlawful object, but also knowledge that a finite group of potential victims, which includes the actual victim, will probably die. These two mens rea requirements should be kept distinct and courts should avoid the danger of bootstrapping the constitutionally required knowledge of death issue by focusing on the dangerousness of the unlawful object.

The constitutionally significant mens rea issue under s. 229(c) is not whether the commission of arson or robbery or the carrying of weapons is a dangerous activity that presents a risk of death. Rather, the constitutionally significant question is whether the accused knew that someone's death was likely at the time that the accused committed the acts that in fact were a significant contributing cause of the victim's death. Courts should consider reading in a requirement that the accused know that death would likely occur to a specific and distinct class of people that includes the actual victim, so as to avoid the dangers of convicting people of murder for accidental or reckless deaths. In other words, triers of fact should be asked whether the accused knew that it was probable that someone in a determinate class, which includes the actual victim, would probably die and be specifically reminded that subjective advertence to the risk or possibility that someone would die is not enough.

The courts also should affirm the importance that the requirement of knowledge of death should be present at the time of the acts by the accused that actually caused death. Although some allowance may be made for a continuing transaction, ${ }^{108}$ the knowledge of death should occur at the same time as the actus reus of causing death is committed. The requirement of fault that is contemporaneous with the actual causing of death helps to ensure that the constitutionally required fault of knowledge of the likelihood of death is not watered down to recklessness or objective foresight of death. It also helps ensure that the constitutionally required mens rea is not bootstrapped onto the separate question of whether the accused pursued an unlawful object that unfortunately ended in death.

The subjective knowledge of death requirement needs to be made more meaningful by returning to first principles that distinguish between subjective and objective forms of fault. The Court should affirm the importance of subjective principles and create needed space that seemed unfortunately to be lacking in the arson cases of Magno ${ }^{109}$ and Roks $^{110}$ between a conclusion (1) that a reasonable person would have recognized risks to life and (2) actual subjective knowledge that people will die in the pursuit of an unlawful object and knowledge that was concurrent with the actions of the accused that in fact caused the victim's death. Courts need to stress that recklessness or awareness of the risk or possibility of death is not a sufficient form of fault either under a plain reading of s. 229(c) or when the constitutionally required mens rea for murder is considered. 


\section{CONCLUSION}

Section 229(c) was an awkward and troublesome section before the Charter, and its recent revival is unfortunate. In many respects, the law of murder would be simpler and more principled had the Supreme Court invalidated the section in its entirety or if Parliament had repealed it. Parliament has, however, not even bothered to repeal the objective arm of s. 229(c) that was found by the Court to be unconstitutional in Martineau, and this failure presents a trap for trial judges. In at least three cases, trial judges have allowed the jury to read s. 229(c) as it is written in the Criminal Code, requiring new murder trials to be ordered because of such embarrassing mistakes.

The avoidance of such mistakes in the future will not be sufficient to deal with the problematic revival of s. 229(c). It will be necessary to revisit pre-Charter jurisprudence. Following Vasil, courts should make clear that the prosecutor must prove an unlawful object that is distinct from the actions that cause the victim's death. A failure to do so will mean that s. 229(c) could eclipse the rest of s. 229 and be used on a routine basis for murder charges. There is a danger that s. 229(c) will not only take over the other murder sections, but also invade the territory of manslaughter by applying to accidental deaths that occur during an unlawful act in the pursuit of an unlawful object.

It will not be enough to insist on proof of a distinct unlawful object. The second mens rea requirement of s. 229(c) — knowledge that death was likely to occur at the time that death was caused - is now the most constitutionally significant of the two fault requirements of s. 229(c). In order to ensure a meaningful constitutional fault element, courts should unpack the deceptively simple shorthand of a "subjective foresight of death.” In doing so, they should make clear to the trier of fact that the prosecutor must establish subjective knowledge of the probability of death to a group of determinate victims, which includes the actual victim. Without this specificity, there is a danger that the constitutional fault for murder will be watered down to include reckless or even negligent murder. In addition, this guilty knowledge of the likelihood of death must be present at the time of the accused's acts that actually caused the victim's death. Without such requirements, the revival of s. 229(c) will dilute the constitutionally required fault for murder. At worst, it will revive constructive murder where a person who causes death is punished for causing death in the pursuit of an unlawful object, and at best it will recognize reckless murder. In either event, it will strain the need for principled and meaningful distinctions between murder and manslaughter.

The most problematic uses of s. 229(c) have not been Meiler or the Jane Creba case where the accused appears to have formed the intent to kill one person, but has killed another by accident or mistake. In such cases, the accused has the necessary fault for murder. Nevertheless, the reluctance of courts to apply the transferred intent provisions of s. 229(b) is odd given the need to give that provision a purposive interpretation and the fact that a person convicted under that section clearly has sufficient blameworthiness to merit a murder conviction. Cases like Côté are also not problematic as the accused seems to have the intent necessary under s. 229(a).

The most problematic s. 229(c) cases so far are the Toronto arson cases, in which accuseds have been committed and convicted of murder for accidental deaths that occurred during the pursuit of the arson even though they had no intent to kill or harm any person. These are cases 
where the high stigma and penalty of murder is being applied to manslaughter and where concerns about the revival of constructive murder are most accurate. In order to prevent disproportionate murder convictions in such cases, courts should recognize that the ambit of what remains of s. 229(c) is restrained by a principle of fundamental justice that a person, even a criminal who is pursuing an unlawful object, should not be convicted of murder for an accidental death. Section 229(c) is also restrained by the principle that unintended harm not be punished as severely as intended harm. These principles have long been recognized within the criminal law and are principles of fundamental justice under s. 7 of the Charter. Respect for them is necessary to maintain a meaningful distinction between murder and manslaughter and to ensure that a person is not excessively and inappropriately punished and labelled a murderer. 